\title{
Ada Salas: un lirismo en harapos
}

Jaime Ávila-Martínez

\section{(2) OpenEdition \\ Journals}

\section{Edición electrónica}

URL: http://journals.openedition.org/agedor/826

DOI: 10.4000/agedor.826

ISSN: 2104-3353

\section{Editor}

Laboratoire LISAA

\section{Referencia electrónica}

Jaime Ávila-Martínez, «Ada Salas: un lirismo en harapos », L'Âge d'or [En línea], 6 | 2013, Publicado el 01 marzo 2013, consultado el 02 mayo 2019. URL : http://journals.openedition.org/agedor/826 ; DOI : 10.4000/agedor.826 


\section{ADA SALAS: UN LIRISMO EN HARAPOS}

Résumé : La voix d'Ada Salas fait advenir un néo-lyrisme qu'il convient d'interroger, dans la mesure où il fuit plus qu'il ne se donne. Parole déchirée qui sollicite le lecteur dans la création de sens, qui en fait a fortiori son herméneute et son interprète, tant le poème semble devenir une partition à déchiffrer, avec ses rythmes et ses pauses. Cette œuvre qui se fait en se défaisant nous met face à un lyrisme en lambeaux, bribes synonymes à la fois de jouissance et de peine qui font vaciller la structure de la poésie et du monde. Néanmoins, cette voix chancelante échappe à son extinction et s'accomplit justement dans la tension qui l'anime.

Mots-clés : silence - absence - Ada Salas - poétique - esthétique - métaphysique - Espagne

Resumen: La voz de Ada Salas hace advenir un neolirismo que conviene analizar, en la medida en que éste huye más de lo que se entrega. Palabra desgarrada que solicita al lector en la creación de sentido, que hace de él a fortiori su hermeneuta y su intérprete, en cuanto el poema parece convertirse en una partitura por descifrar, con sus ritmos y sus pausas. Esta obra que se hace deshaciéndose nos pone delante de un lirismo en harapos, fragmentos sinónimos a la vez de gozo y de pena que hacen vacilar la estructura de la poesía y del mundo. Sin embargo, esta voz vacilante se salva de la extinción y se desarrolla precisamente en la tensión que la anima.

Palabras clave: silencio - ausencia - Ada Salas - poética - estética - metafísica - España

$\mathrm{E}$ 1 poemario de Ada Salas titulado Variaciones en blanco podría leerse como la representación de la ausencia. Transgrediendo así el límite entre esas categorías que fundan nuestra relación con las cosas y que conducen a interrogar su verdad, esta poesía forajida se percibe como una poesía del estallido luminoso que acaba con lo apagado, lo oscuro - poesía, podría decirse, en la que el verso desaparece en la serpiente lacerada en múltiples trozos por la rotura de cristales y vidrio que no acaba nunca de renacer y de regenerarse en la ondulación de su forma entre fragmentación y unidad: «le texte ne doit pas naitre d'une idée pas plus qu'il ne doit y conduire; il ne consistera pas en un parcours immobile du sens.» ${ }^{1}$ Va siendo manifiesto el vaivén entre una doble isotopía que teje el horizonte de lectura: los poemarios aquí estudiados vacilan entre imperfección, alusión, pasaje por un lado, y perfección, totalidad de la obra ausente, plenitud de otro lugar, sinónimo de felicidad, objeto de gozo por otro lado. A la obra total, que encuentra su fin en sí misma y que se plantea como un absoluto, se puede oponer la

${ }^{1}$ Marie-Claire Zimmermann, Poésie espagnole moderne et contemporaine, Paris, Armand Colin, 2005, p. 158. 
imagen truncada de ese otro lugar que designa o hacia el que tiende nuestro corpus, si - para retomar a Mallarmé - «tout, au monde, existe pour aboutir à un livre.» ${ }^{2}$ Son esa forma informe, ese espejo en pedazos que debemos interrogar.

Ada Salas se inscribe en el surco de la experimentación que lleva al lenguaje hasta sus límites, y de alguna manera los sobrepasa. El plural en el umbral al poemario de Ada Salas sugiere las diversas imitaciones de un mismo tema. La obra se encuentra así en un punto posterior al final y anterior al principio, sea en la eternidad sea en la actualidad del instante:

Écrire, c'est disposer le langage sous la fascination et, par lui, en lui, demeurer en contact avec le milieu absolu, là où la chose redevient image, où l'image, d'allusion à une figure, devient allusion à ce qui est sans figure et, de forme dessinée sur l'absence, devient l'informe présence de cette absence, l'ouverture opaque et vide sur ce qui est quand il n'y a plus de monde, quand il n'y a pas encore de monde 3 .

La ausencia se plantea como elemento activo de la creación discursiva y semántica. Lo poético - entendido como lo que participa de la idealidad, espiritualidad y belleza de la poesía - y lo poemático - que definimos como la materialidad de la poesía, su espacio, condiciones y medios de realización, su concreción en signos gráficos, en versos - pasan por una prueba de fuego, la de la logofagia, de la que no salen intactos. De hecho, cierta incomprensión gravita alrededor del resultado que no deja de presentar características herméticas. Algo tienen de festivo en este hermetismo, ya que transgrediendo el orden habitual de la creación de sentido y de nuestra relación con los textos, la obra de Salas implica la participación colectiva. Celebración discordante, heterogénea, que incluso no remite a ningún contenido a veces, los poemas no tendrían sentido. Ni enseñanza moral, ni comunicación de un mensaje; la ausencia de sentido podría ser también una reivindicación poética y poemática recusando un avance lineal en aras de una construcción en espiral de la reflexión. Lo que tiene de festivo este poemario lo sitúa del lado de la ruptura con lo habitual, puesto que tenemos textos que baten en brecha el fluir ordinario del cauce poemático y del agua que por él pasa. Se erigen en verdaderos jeroglíficos que no remiten a ninguna época, velando y desvelando los posibles senderos interpretativos. Es que más que de una ausencia total de sentido se trata de la desaparición de un solo sentido, de una liberación. En este universo asistimos a la violencia de un parto - el de la obra - y al parto de la violencia - la de la lucha que es la lectura -, asistimos a la celebración de la Nada, soledad, vacuidad, reflejos, fantasmas que reproduce hasta el infinito la poesía en su reflexividad, en las variaciones de su música. Atrae y asusta, fascina y repulsa el vértigo de esos juegos de espejos en los que la estructura entera - del poemario, del mundo - acaba por derrumbarse. Pero finalmente se salvan la belleza un tanto barroca de la escritura, la violencia estética de una lengua en la que el lirismo se codea con su muerte, la autocelebración de la poesía. Cabe preguntarse entonces: ¿cómo la escenificación discursiva de la ausencia acaba mermando lo poético y lo poemático, redefiniéndolos, convirtiéndose a la vez en cuerpo y sangre de los mismos?

2 Stéphane Mallarmé, «Quant au livre », Euvres complètes, Paris, Gallimard, Bibliothèque de la Pléiade, 1945, p. 378.

${ }^{3}$ Maurice BLANCHOT, L'Espace littéraire, Paris, Gallimard, 1955, p. 31. 
En las convulsiones de esta crisis llamada poesía se fragua nuestro corpus. Esta agitación tiene como consecuencia el advenimiento de una poética del estallido luminoso, plasmado en la nada visual. Beben pues nuestros textos de una estética del fragmento y de la ruptura, de una violencia constitutiva, de ahí que se arraiguen también en una metafísica de la consumición. Sin embargo escapan a la dilución, constituyéndose como obra, pero una obra que se hace deshaciéndose, siendo un pasaje, ya no en el sentido de intermediario o de reflejo, sino en el de revelación de la obra definida no como realización sino como pura tensión.

\section{I - Una crisis llamada poesía}

En el umbral de este estudio, conviene recordar la etimología del sustantivo «poesía», que remite a un momento en el que algo sale de la nada, en el que algo existe; es un tiempo decisivo, un tiempo de decisión y por ende un tiempo de crisis. Cabe aludir una vez más a la etimología para explicitar el vínculo intrínseco que acabamos de establecer: en efecto, la palabra «crisis» en griego significa «decisión». El tiempo de la poesía, su momento es crisis, condición inherente a un género cuyo nombre mismo designa el acto de creación. Esta afirmación es también la de Christian Prigent, para quien « la crise est l'état normal pour celui qui entre dans l'étrangéité des langues» ${ }^{4}$, hasta el mismo sujeto poético se ve afectado por ella y padece sus desgarramientos. Se percibe particularmente en las obras que comprenden la poesía como una experimentación ontológica y lingüística, a la que pertenece la obra de Ada Salas. Para ella,

la fase más ardua del proceso de escritura es ese barrido, ese vaciamiento que, a través de un desasimiento paulatino de la vida, del yo nuestro en el mundo de los demás, se traduce en una espera vigilante, alerta. Vacío, silencio, soledad. Nada. Ausencia. ${ }^{5}$

Conviene, pues, detenernos en su misticismo sin panteón. Y nuestra mirada no ha sido la primera en reparar en ello: Marie-Claire Zimmermann habla de la « hypothèse d'une entité divine » en una obra - la de Jaime Siles - que "se présente radicalement comme l'écriture d'un monde immanent où l'homme est en quête d'être, mais d'un être non transcendant.» ${ }^{6}$ Partiendo de esta observación que transferimos empíricamente a la obra de Ada Salas, parece que el único espacio de realización del ser es el lenguaje, con todo y las dificultades enunciativas que esto supone. Y el mejor marco para este despliegue ontológico es el poema. De ahí que éste rezume misticismo.

En la poesía de Ada Salas se abandona la referencia al panteón cristiano para aludir a la mitología retomada por Garcilaso en sus poemas. En Alguien aqui — sus apuntes sobre la

\footnotetext{
${ }^{4}$ Christian PRIGENT, Ceux qui merdRent, Paris, P.O.L, 1991, p. 206.

${ }^{5}$ Ada SALAS, Alguien aquí, Madrid, Hiperión, 2005, p. 14.

${ }^{6}$ Marie-Claire ZIMMERMANN, «Nommer un dieu sans religion. Lecture de l'œuvre poétique de Jaime Siles », HISPANÍSTICA XX, 21, 2003, p. 416
} 
escritura poética -, Ada Salas afirma que «las ninfas de Garcilaso son tan reales ahora como lo fueron entonces: su materia es el humo de las palabras. ${ }^{7}$ En esto radica una segunda distanciación: la inmanencia de lo sagrado en el lenguaje. Es que el lenguaje produce lo sagrado, es lo sagrado en cuanto constituye el barro de la realidad lingüística, de manera que la visión se ve supeditada a la palabra. Se reconoce entonces toda la pertinencia del valor programático del poema liminar de V ariaciones en blanco.

\author{
Palomas \\ de penumbra de pluma \\ caedizas. \\ Lento día de plata \\ lenta \\ mirada mía \\ sumisa a mi palabra.
}

Esta pieza liminar nos introduce en una poesía de lo nominal, de lo esencial. Se inicia con un vuelo sugerido por el valor semántico de las «palomas» que abren el texto. Son varias y su plural remite a las «variaciones» del título del poemario. Suspendidas en el tiempo de la lectura y en el espacio del poema por el blanco tipográfico que las sucede, las «palomas» invitan al lector a domesticarlas, a seguirles la cola, quizá incluso a interrogarse sobre el mensaje que llevan, velado tanto por el silencio como por el matiz de su color. Inmediatamente después de la visión de las «palomas», las aves son irrealizadas por su esencia que nos da el complemento del nombre al caracterizarlas «de penumbra de pluma/caedizas». Son tanto más irreales cuanto que se introduce en ellas la sospecha del silencio, del blanco que ya ponía de manifiesto la «penumbra», esa sombra débil entre luz y oscuridad, que las funde ambas, que no deja percibir dónde empieza la una o acaba la otra. A lo que apunta además la penetración del blanco tras el sustantivo "pluma», es a crear una interacción entre el texto y el no-texto, a señalar la delicadeza del uno y la fuerza corruptora del otro, a difuminar lo certero de la tinta en lo borroso de la página, a sumirnos pues en una lectura en suspensión que es presencia de sentido. En efecto, la voz poemática se calla para mostrar la fragilidad del decir y de lo que se dice, de esas «palomas» o palabras, mejor aun, de esas palomas de palabras tan «caedizas». Subsiste únicamente «la superficie mansa y lacustre del silencio» ${ }^{8}$, cuya manifestación gráfica es el blanco y cuya variante sonora reside en la aliteración en la nasal $/ \mathrm{m} /$, si admitimos que existe en el sonido nasal algo de infinitud, de eterno, recordando solamente que según budistas e hinduistas, el «om» es el sonido primordial mediante el cual se sostiene el Cosmos: el símbolo del Absoluto Universal. A esta «superficie mansa» la voz poética «lanza una piedra» ${ }^{9}$ cuya fuerza y violencia manifiesta la aliteración de la oclusiva /p/ (repetida tres veces). Y la caída se pone de manifiesto nuevamente por un blanco tipográfico y una vuelta a la línea que se

\footnotetext{
7 Ada SALAS, Alguien..., p. 56-57.

8 Ada SALAS, Alguien..., p. 13.

${ }^{9}$ Idem.
} 
corresponde perfectamente con el derrumbamiento del lenguaje. Este derrumbamiento resulta en una subversión o inflexión del sustrato bíblico.

Venidos abajo todos los panteones, las imágenes se vacían de la carga religiosa para convertirse en un motivo poético fecundo, en fragua de nuevos ídolos que serán la creación de la palabra poética, el lenguaje, todo lo que remita en fin a un nuevo mundo lingüístico - en gestación. Convocamos aquí el poema de Ada Salas «Ala sin sueño...» ${ }^{10}$ En este poema, surgen imágenes crísticas y la voz poemática se convierte en nueva Verónica o María Magdalena que viene «fiel a abrazarte/mal/de tus heridas.» Pero el único rostro que nos trasparece en la sábana santa del poema es el de la poesía herida a la que la voz poemática implora u ordena (el imperativo en el texto original admite ambas lecturas) que «abr[a] dócil la llaga». Y cuando no es la poesía misma a la que se dirige, se trata entonces de un desdoblamiento del sujeto lírico en el espejo de la poesía, tal y como lo evidencia el combate identitario entre el yo y el tú en el poema «Deja en mi pecho....» El «fruto» esperado, el que se encarna aquí es el de la «fiera semejanza». Y cómo no vislumbrar en los versos siguientes las ruinas de la eucaristía religiosa sobre las que se yergue la transmutación poética y lingüística: «Alza/lenta la sombra/en blanco/de tu gesto./Su imposible perfil/me hiera.» ${ }^{12}$

Es de notar pues el abandono total de la referencia explícita a un dios, término que no aparece nunca en Variaciones en blanco, siendo el único superviviente del imaginario religioso el «ángel», figura de la que se hace mención dos veces solamente. Y es que el verbo se vuelve Verbo: palabra creadora de palabras y de silencio, de «totalidades»: «Todo signo penetra claridad./[...]Todo signo insiste en el silencio./Pero no lo desvela: lo produce.» Produciéndolo, nos sume en un bic et nunc eternizado, atemporal. Prueba de ello encontramos en los versos de Ada Salas cuando la voz poemática nos dice que

\section{Aquí}

fluye sólo el silencio

inconsolable. ${ }^{13}$

Los mismos versos constituían ya el poema de la página 13, salvo que sin el deíctico de lugar, en el que se esconde muy sutilmente la marca casi imperceptible de la primera persona si tenemos en cuenta la localidad a la que remite dicho adverbio. Lo que fluye «aquí», en el espacio eterno de la página, no son ya las palabras que apenas sirven para encauzar una lectura sino «sólo el silencio». Ese fluir lo garantiza la aliteración en la líquida $/ 1 /$. Permite también esa continuidad que sugiere el verbo el blanco, puntuación si se quiere pero completamente renovada en su función ya que no pone fin al texto sino que lo prolonga, lo estira hasta un más allá de la frontera gráfica para que pueda entonces surgir y

\footnotetext{
10 Ada SALAS, Variaciones en blanco, Madrid, Hiperión, 1994, p. 22.

11 Ada SALAS, Variaciones..., p. 23.

12 Ibidem, p. 26.

13 Ibidem, p. 73.
} 
escucharse el sonido, la imagen, el pensamiento. Y lo que se piensa o se da a pensar es una poesía continua, una poesía sin principio ni fin en constante metamorfosis. Esta continuidad reposa únicamente sobre «el silencio», de ahí su posición central en el poema sea por los signos gráficos que lo nombran sea en la blancura que los devora. Es de notar la continuidad que pone de realce aun más la infinitud contenida en el prefijo negativo de «inconsolable» ${ }^{14}$, así como en la aliteración en la nasal /n/ que recorre todo el texto. Pero justamente porque la pena no tiene alivio, el único remedio posible es abrazarla a cuerpo entero de manera que se establece un pensamiento innovador, pensamiento de la unidad, de la interdependencia de los contrarios que se alían en nupcias trascendentes: pena y alivio son una misma experiencia, la de una nueva coherencia que radica en un movimiento perpetuo de lectura en busca de un sentido huidizo que nunca termina de ser descifrado. No olvidemos pues lo común que tienen lo secreto y lo sagrado, que es precisamente esa aureola de misterio que los enmarca.

Si este misticismo sin panteón cuyo único dios es el lenguaje no peca por su originalidad, al menos tiene el mérito de ser originario, siguiendo el precepto unamuniano que Ada Salas cita en la página 119 de Alguien aquí: "“no hay que ser originales, sino originarios"». Y en esta búsqueda de lo originario ausente, nos encontramos delante del negativo de un neoplatonismo.

Se transparenta en el poemario salasiano une relectura de Platón. En efecto, los textos reactivan el papel prometeico del poeta, de modo que plantean el papel del poeta como guía, como personaje iniciático que ostenta la antorcha. La salvedad aquí radica en que el mundo de las Ideas no es un más allá sino, como lo hemos sugerido antes, un más acá. Por eso, más que de un ascenso hacia la salida de la caverna, se trata de un descenso por excavación: el único objeto real - ausente - no es la concreción de la imagen sino su negativo, su substrato. Es que:

De algún modo el poema subyace, informe. La labor del poeta es hundirse en la cueva primigenia y alumbrar. Recorrer luego el estrecho pasadizo y rescatar a la idea de su sueño ${ }^{15}$.

No cabe la menor duda a la luz de este postulado que el sujeto poético se erige en ladrón del fuego con el que ilumina la oscuridad del ser, su impenetrabilidad. Y a la respuesta siempre diferida por el carácter escurridizo del ser, se sustituye una palabra que se dice y que dice su función, una palabra que es visión pues «fulgen sólo estos ojos/que dirán lo que han visto.» ${ }^{16}$ Ojos que son el espejo del alma y, por tanto, es toda ella llama que arde de conocimiento, reflejo del poeta visionario y mensajero. Abundan las alusiones al elemento iluminador, siempre asociado directamente con la voz poemática, inherente a ella, congénito podría decirse: algunas páginas después, por medio de una metáfora pictórica pasamos del poeta visionario al poeta pintor que imprime aquello que le permite ver «el ascua de [su] frente». Poco a poco el fuego lo consume todo, transfiriéndose del visionario a la visión puesto que «arden la sombra y sus hogueras/y la luz/y sus lagos», convirtiéndose

\footnotetext{
${ }^{14}$ La cursiva es nuestra.

15 Ada SALAS, Alguien..., p. 15. La cursiva es nuestra

16 Ada Salas, Variaciones..., p. 16.
} 
en origen de la misma. Esta alianza de la palabra y de la imagen visual reactiva el ut pictura poesis horaciano, resultando por ejemplo, en el poema «Vengo del aire manso...»" , en una escena apocalíptica.

Entiéndase el adjetivo «apocalíptica» en sus dos acepciones: el lector asiste a una revelación gracias a la voz poemática que «h[a] visto la hora blanca/en que todo se agita». No puede pasar desapercibido el simbolismo del color que reviste este momento particular, color de la luz solar sin descomponer en los varios matices del espectro, color de la virginidad, de lo originario. Y la fuente de la que brota la imagen es bien la palabra; de ahí la fuerza de la prohibición final del poema, cuando el sujeto poético exige que «nadie ciegue [sus] labios», metáfora en la que la visión y el lenguaje quedan intrínsecamente ligados, son una misma cosa, son poesía tal y como la definía Jaime Siles, es decir «un acto de Realidad y de lenguaje». Llama la atención de cualquier lector esa mayúscula que distingue dos realidades: una que quizá podríamos calificar de falsa o al menos adscribirla - mejor aun, relegarla - a un segundo rango, y otra que sería la que nos da el poema, la única, la verdadera, la de «la hora blanca», blanca porque surge de los blancos tipográficos que confieren al texto todo su sentido ponderando el ritmo y las palabras, siendo artífice de significado. $\mathrm{Y}$ es que «no es lo que el lenguaje da, sino lo que el silencio niega. Y no se niega el signo, sino el ser. Y más aún: el mundo, que como concreción del ser se nos

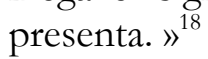

Todo proceso enunciativo y por tanto cognitivo tiene su fundamento en el silencio, en el negativo del lenguaje; pero no se trata de una mera negación, sino de un negativo en el sentido fotográfico por el papel revelador que desempeña. De ahí que, sacado a la palestra, el silencio nos indique «el verdadero movimiento del poema [que] no va del absoluto hacia las cosas sino de éstas hacia el absoluto» ${ }^{19}$, siendo éste la nada sonora subyacente a todo texto.

No se trata de un movimiento ascendente sino descendente como hemos apuntado antes, sustentando nuestra lectura negativa - en un sentido fotográfico, recordémoslo - de la utilización de Platón por los autores de los que aquí discurrimos. Conviene también mencionar:

[...] le rôle essentiel du langage ; considéré comme élément de la réalité, mais d'une réalité cachée, en secrète corrélation avec l'être, dont il convient d'apprécier les multiples manifestations depuis et par le langage. Un langage qui, de cette façon, sera tout autant sujet qu'objet $^{20}$.

¿Cuáles son pues esas «múltiples manifestaciones» del ser? Nos llama la atención a su vez la curiosa dedicatoria de V ariaciones en blanco, en la que Ada Salas rinde homenaje «a [su] padre/y a su fértil memoria.» ${ }^{21}$ Comentario irónico o sincero, poco importa; lo que sí cuenta

\footnotetext{
${ }^{17}$ Ibidem, p. 42.

${ }_{18}$ Jaime SILES, Tratado de ipsidades, Málaga, Begar ediciones, 1984, p. 36.

19 Jaime SILES, Poética y poesía, Madrid, Fundación Juan March, 2007, p. 36.

${ }^{20}$ Henry GIL, La poésie de Jaime Siles : langage, ontologie et esthétique (1969-1999), Lyon, ENS Éditions, en prensa.

${ }^{21}$ La cursiva es nuestra.
} 
es que desde uno de los primeros umbrales de entrada en su poemario, la poetisa coloca su obra bajo el signo de la reminiscencia. Más adelante pedirá a la soledad que «re[ce] un aria gemela a [su] memoria.» ${ }^{22}$ Cabe subrayar la paradoja de este verso puesto que semánticamente el verbo se opone al objeto de su realización: quizá se nos invite a encontrar cierta melodía en el ritmo de la recitación para hacer de la invocación a la memoria algo eufónico. Eufonía que sería la de la música, única fuente de vida y garantía de existencia incluso para el pensamiento ${ }^{23}$, en un proceso que Juan José Lanz define como una «esencialización de la palabra poética.» ${ }^{24}$

Aunque se reactiven principios neoplatónicos, no deja la autora de pervertir sus márgenes, invirtiéndolos parcial o totalmente como a través de la afirmación paradójica de un substrato primigenio y a la vez la consumición del mismo en las llamas del fuego heracliteano del devenir, del cambio y del movimiento constantes. Nos acogemos nuevamente a las luces de Juan José Lanz quien apunta ese:

proceso de absolutización lingüística, de retorno a las fuentes originarias del lenguaje, en que el Ser hecho Logos es uno con la Realidad que nombra, y se hace uno en el mismo acto de nombrar. ${ }^{25}$

Dicha afirmación es verificable en cantidad de poemas de Ada Salas. Con todo, puede ponérsela en tensión con el devenir del que hemos hecho mención anteriormente y que patentizan los textos del poemario en cuestión. En efecto, en Variaciones el blanco, la recurrencia en los poemas de la idea de fuego, sea contenida en un verbo, en un adverbio o en alguna imagen, sea que el término esté presente en los versos, es abrumadora: véanse por ejemplo las páginas 25, 29, 38 y 42. Encontramos la alianza de contrarios, el recurso a la antítesis cuando fuego y agua se vuelven uno, «como río que/arde.» ${ }^{26} \mathrm{Y}$ es que es imposible capturar la poesía, fugaz, fogosa, «rosa/ardida al calor de tu verso ${ }^{27} »$, nos dice Ada Salas. El verso a su vez se convierte en «sombra/mía», es decir en proyección oscura de la voz poemática, de su cuerpo, de su ser; proyección de la que sólo vemos los contornos y en cuyo seno la:

démarche conceptuelle met en avant un éloge de la forme et de l'art, lesquels semblent être les seuls à pouvoir revendiquer une certaine éternité, dans la mesure où ils nous suggèrent par-delà leur présence une certaine invisibilité capable d'être frôlée par instants, et d'où peut jaillir une épiphanie de l'être. ${ }^{28}$.

Hemos apuntado la incapacidad de apresar el arte y el Ser. No obstante el poeta ve la esencia, ve el Ser en y a pesar de su fugacidad: «el poeta es un visionario de lo real: no ve al

22 Ada SAlAS, Variaciones..., p. 14.

23 «Mientras suena la música, perdura,/más allá de sí mismo, el pensamiento [...]», versos del poema de Jaime

Siles titulado «Gedanke», en Música de agua, Madrid, Visor, 1983, p. 30.

24 Juan José LANZ, art. cit., p. 340.

25 Ibidem, p. 343.

26 Ada SALAS, Variaciones..., p. 25.

27 Ibidem, p. 38.

${ }^{28}$ Henry GIL, op.cit., p. 42. 
hombre, sino su esencia.» ${ }^{29}$ Por eso emprende una búsqueda, una reflexión sobre el Ser. En el poema de Ada Salas "Acaricio el temor...»", se puede apreciar la sensualidad del contacto con lo horrible. Entiéndase aquí el horror como el sentimiento causado por algo espantoso, según la definición de la Real Academia, y por ende léase sobre todo su vínculo con lo sagrado por ser esto también espantoso en cuanto es maravilloso, asombroso. La vOz poética alude al «oscuro reclamo/de [su] nombre». Se entiende que la voz va construyéndose otro ser que el lenguaje no nombra, sino que oculta y que ese ser por su oscuridad puede ser cualquiera. Encontramos una perfecta resonancia de esta lectura en otro poema - «Si has de morirme» - que se sitúa en la página 72. Los mismos campos léxicos y la vinculación entre ellos autorizan el cotejo de ambos textos, sustentando así las interpretaciones propuestas, tanto más cuanto que el velo de duelo que vuela sobre dichos poemas parece dar a luz a un poeta que mira escurrirse su identidad ${ }^{31}$. Barruntamos que si el poema permite pulsar el ser, si es un "déploiement d'intense activité ontologique et linguistique ${ }^{32} »$, únicamente palpamos y tanteamos un ser - que ya no el Ser heideggeriano aunque éste sirva de trasfondo -, ni mucho menos el ser del poeta.

Finalmente lo que se pulsa no es el Ser, sino un ser, el del lector que se proyecta en la pantalla poemática ${ }^{33}$.

Hemos pasado de una etapa de olvido del yo, de su desmaterialización a una fase de anagnórisis. «Se la produce el texto», como el espejo produce nuestro reflejo. Convocamos aquí el diálogo con el «tú», que es consabido principio de definición del «yo», que aparece en el poema de Ada Salas, «Acógeme....» ${ }^{34}$ Bien podría definirse el esquema temático del poema como el siguiente: yo-tú-yo.

\author{
Acógeme \\ que vengo para hablarte \\ y en el ojo estancado \\ de tu calma \\ al fin
}

me reconozco.

El principio, la primera persona, es el final del texto; esta circularidad remite a la especularidad antes mencionada. El poema se convierte en el único espacio en el que la anagnórisis es posible. De manera que sobre las ruinas existenciales y estéticas la escritura

\footnotetext{
29 Ada SALAS, Alguien..., p. 131.

30 Ada SAlas, Variaciones..., p. 32.

31 Jean-Michel Maulpoix, Le Poète perplexe, Paris, José Corti, 2002, p. 224.

32 Marie-Claire ZimMERMANN, op. cit., p. 185.

33 Jaime SILES, Poética y poesía, Madrid, Fundación Juan March, 2007, p. 30.

34 Ada SALAS, Variaciones..., p. 44.
} 
se vuelve pintura del yo poemático, «inmaculado lienzo/a mi cuerpo en ceniza ${ }^{35} » ;$ pero se ha desplazado el sujeto elocutorio del poeta al lector, cuyo ser es «ceniza» recogida en el «ebrio golfo de luz». La imagen lumínica ascendente tiene por correlato el «cálido cuenco» que cierra el poema, es decir ese recipiente de barro en el que se da forma a lo informe, al ser del lector en cuya interioridad nos sumergen los textos. Asistimos pues en la página 56 a un espectáculo natural en el «yo» admirado por un «tú», a un crepúsculo interior que parte de la memoria: el verbo «recuerda» abre el poema. Asimismo en el poema siguiente la evocación parte una vez más del «recuerdo» proferido por la voz, aquí desdoblada en un «yo» y en su «sombra». Bien podría leerse más que un desdoblamiento quizá una reunión, una fusión de ambos que acaba en una fundición del sujeto elocutorio en el silencio. El silencio es quien habla en lo que podríamos llamar entonces una anagnórisis reflexiva.

En fin, podemos decir de Ada Salas lo que Juan José Lanz dice de Jaime Siles, que su voz nos propulsa en una «búsqueda de la esencia que constata su ausencia.» ${ }^{36}$ Ausencia que radica en la fugacidad del ser, que no es más que « une multitude de voix dont l'essence est un son surgi du blanc et qui retourne au blanc» ${ }^{37}$, y cuyo transparentarse se descubre gracias a " une ascèse langagière - qui est aussi une écriture à rebours - un silence sonore situé aux limites extrêmes du langage, au bord du vide et du vertige.. ${ }^{38} \mathrm{Y}$ este vértigo es el resultado de una poética del estallido luminoso.

\section{II - UNA POÉTICA DEL ESTALLIDO LUMINOSO}

En la poesía salasiana, se trazan los desgarramientos provocados por la crisis que es el resultado a su vez de los sujetos en crisis. De modo que pone en evidencia « l'affleurement sempiternel de la crise dans la langue (ce que Mallarmé appelait "la crise de vers")..> Es de subrayar la violencia del gesto, del estallido tanto más luminoso cuanto que del hoyo que abre surge la poesía, de esa ausencia de plenitud morfosemántica. Por eso la poética de esta obra reside tanto en su explosión como en su destello: en el hoyo abierto del Ser cuya esencia es su ausencia misma, en el hueco que permite la reverberación de ecos, en el blanco que remite al sinfín de colores que contiene su espectro, en el derrumbamiento que hace de las ruinas creación. Es como si la poesía no cesara de cuestionarse, sustrayéndose a las formas consabidas, sustrayéndose al lirismo ${ }^{40}$, sustrayéndose incluso hasta a la significación y la textualidad, volviéndose in fine la forma informe de la crisis que la originó y que le es inherente. Crisis que es la de la lucha de la escritura contra el silencio, que, por ende, es su marco, su margen de acción y la condición intrínseca de todo discurso. Túa Blesa identifica en una cita del Libro del Tao de Lao Zi el

\footnotetext{
35 Ada SALAS, Variaciones..., p. 45.

36 Juan José LANZ, art. cit., p. 353.

${ }^{37}$ Henry GIL, op. cit., p. 51.

38 Henry GIL, op. cit., p. 51.

${ }^{39}$ Christian PRIGENT, op. cit., p. 206-207.

40 En cuanto al lirismo, matizaremos más adelante esta aserción apoyándonos en la obra de Jean-Claude PINSON titulada Habiter en poète.
} 
planteamiento del problema, de la tragedia del escritor: «El que sabe no habla», dice el sabio chino. Túa Blesa a su vez concluye que:

el que hace de su trabajo un problema, una razón de existencia [...] no puede hablar a la ligera, algo hay que le impide trazar su caligrafía, y, en esa agonía, quien reina es el silencio, que pugna por imponerse. ${ }^{41}$

En esta lucha se inscribe el dilema de la voz poemática en los textos de que aquí tratamos. Habiendo establecido que la esencia del Ser es no ser, su ausencia, queda sin embargo en el poema otro ser que es la voz poemática. Ésta oscilará según las veces y la modalidad del «yo» adoptada entre una presencia explícita, una manifestación oblicua o una ausencia total cristalizada por la impersonalización de algunos textos. De modo que el dilema - el ser o no ser - se encuentra en el corazón de la búsqueda de la voz por encontrar su sitio. Ada Salas procederá a un duelo, afirmando que «el yo que vive se enfrentaba descarnadamente al yo que escribe.»» ${ }^{42}$ En efecto, «[l]e interesa el poeta que se transparenta en el poema casi a su pesar, no el que se impone.» ${ }^{43}$ No faltarán en su poemario piezas que rezuman de lirismo en el sentido estricto de la palabra. Y sin embargo unas páginas más lejos nos dice que «el gran poema es el que desposee al autor, lo anula, se impone a él hasta borrarlo.» ${ }^{44} \mathrm{La}$ articulación de ambos planteamientos no deja de suscitar perplejidad y de presentarse como problemática. Conviene retomar la tabla de claves utilizada por Henry Gil para el estudio y la elucidación que aportan estas voces a la pregunta que las habita, las anima y a veces las merma.

En V ariaciones en blanco, hemos encontrado 15 poemas que partirían de este principio de escritura de la impersonalización. Otra categoría establecida por Henry Gil es la de aquellos poemas en los que se observa una presencia restringida u oblicua del «yo». Entran en esta clase ocho poemas de V ariaciones en blanco. Finalmente la voz bajo la modalidad de la primera persona del singular se hace presente explícitamente en 41 poemas de Ada Salas. Es evidente que en el poemario de Ada Salas sobresale la presencia explícita de un «yo». Efectivamente, la carne y el «cuerpo propio» ${ }^{45}$ están presentes en los poemas de Ada Salas. De manera que se reúnen las condiciones para encaminarse hacia una nueva forma de subjetividad. Nos detenemos pues con la lentitud que pide el poema en la quinta pieza de $V$ ariaciones en blanco:

Hiere lento
dolor

pausado.

Demórate en la espada de mi cuerpo

41 Túa BLESA, «Logofagias, los trazos del silencio», Tropelías, 1998, p. 14-15.

42 Ada SALAS, Alguien..., p. 24.

43 Ada SALAS, Alguien..., p. 50.

44 Ibidem, p. 60.

${ }^{45}$ Jean-Claude PInson, Habiter en poète, Seyssel, Champ Vallon, 1995, p.84. 
y no descanses.

No quieras acabarme.

Algo de masoquista tiene esta súplica en la que la voz poemática se dirige a una especie de Tánatos, en calidad de personificación mitológica griega de la muerte no violenta, que se representaba como un hombre con una antorcha invertida. El inicio es un tanto violento con el verbo en imperativo que nos sume directamente en el ruego. La violencia del acto perdura y se perpetúa cual deliciosa tortura en el ritmo sugerido por el adverbio «lento». La prolongación masoquista de un placer aflictivo permite la continuación de la escritura, volviéndose el «dolon» motor y condición sine qua non del acto de escribir. Nótese el marcado protagonismo de la sensación personificada por su aislamiento textual. En el blanco resuena el sostenido grito o ruego de la voz poemática, se eterniza y amplía el alcance de Tánatos y de su inspiración, así como en la diseminación fónica de la /o/ cuyo origen griego era el omega, el fin que no es un final porque abre las puertas de la eternidad. Cabe subrayar la importancia de la duración de la contemplación placentera y doliente para aumentar la sensibilidad: herir para dejar lo más profundo de la carne a flor de piel. Herida progresiva, quemadura paulatina, cicatriz de la llama en el papel que va dislocando el pentasílabo y esparciendo su huella - la huella de la logofagia - en el papel. El dolor corroe en todos los sentidos y como agente corruptor se le pide que continúe y prolongue la reacción en el cuerpo asimilado a una «espada», confiriéndole una tremenda sensualidad al poema. Basta con comprobar como los ritmos, las pausas y los sustantivos mezclan en la evocación el amor y el dolor. Volvemos pues a una poesía de lo sentido, en la que aquí se invierten los papeles: «la espada» es herida por el dolor. De manera que se transmuta la realidad, incitándonos la voz poemática a detenernos sobre una visión de placentera tortura, inspirándonos compasión en su sentido etimológico. Sufrimos con ella ante lo que describe la imagen que perdura en el blanco tipográfico que la sigue. Y es que el blanco es el dolor mismo in fine, el dolor que va hiriendo también la comprensión del lector para mejor hacerlo adicto al poema hasta implorar: «y no descanses». Esta poesía que nos desangra para mejor llenarnos nos solicita un esfuerzo continuo, poesía prometeica - si cabe - en la que el titán suplica que el suplicio continúe: «no quieras acabarme.» La posición de pronombre complemento hace de la voz poemática una víctima consintiente que padece para y por seguir clamando.

Es manifiesta la influencia del devenir heraclíteo: del no-ser del yo pasamos a su resurgencia, a su resurrección puesto que no sólo aparece en Ada Salas un yo que se afirma claramente sino un yo que adquiere también corporeidad. De ahí el neolirismo que se desprende de los poemas, si admitimos que «la parole du poète lyrique se fait ainsi l'écho d'une énigme qui est celle de l'Être lui-même.» ${ }^{46}$ Enigma que bajo la pluma de la autora se hará manifestación sensual, experiencia de una voz, de un cuerpo que rinden cuenta de " quelque chose d'essentiel à la posture lyrique : son écartèlement entre un vif sentiment de la finitude et une aspiration à l'infini.» ${ }^{47}$ Esta escisión, esta vacilación provienen de la puesta

46 Jean-Claude PINSON, op. cit., p. 82.

${ }^{47}$ Ibidem, p. 128. 
en duda del realismo y del idealismo, que hace que la posición del sujeto sea inconfortable e incierta ${ }^{48}$.

Rechazando idealismo y realismo, el sujeto poético se vuelve a la vez voyeur y vidente: voyeur de su propia delicuescencia y vidente de un más allá que es en realidad un más acá: el lenguaje. Los temas son soporte viviente de lo esencial, es decir la fascinación del sujeto. Esta fascinación supera los soportes y conlleva al sujeto a sentirse él mismo en el acto de creación-visión. Basta con leer detenidamente el siguiente poema de Ada Salas para admirar dicho acto:

Ya no será la paz.

Han besado

mis ojos

tu terrible desnudo.

El futuro del indicativo no deja lugar a dudas: la situación de la voz poemática es la de un perpetuo desasosiego y cuestionamiento, la de rotunda inquietud. Se abandona cualquier característica edénica por una sinestesia en la que el tacto se aúna a la vista y ambos son motivo del desvelo del mysterium tremendum et fascinans ${ }^{49}$ al que alude Jean-Claude Pinson, encarnado aquí en el «terrible desnudo.» Sacralidad y lirismo se asocian así a la corporeidad y a la sensualidad de la imagen - qué más erótico que un beso, tanto más cuanto que ni siquiera es concreto sino mero producto de la visión. Con todo, la ruptura de un ordo naturalis es patente: se abre el poema con un verso que relata un estado resultando de lo que a continuación se expone, la perfecta armonía de los tres heptasílabos que componen el poema se ve alterada por el escalonamiento del segundo verso escindido en un tetrasílabo y un trisílabo. El dilema nos lleva de la « dissolution du Moi qui va de l'extase au néant, mais où va perdurer l'écho d'une musique» ${ }^{50} \gg$, música cuyo canto servirá de encantamiento resucitador para un «yo» en el neolirismo de Salas, un yo fragmentado, a imagen y semejanza de sus poemas, un «yo» que reanuda en su multiplicidad de rostros vacíos con la «personalidad múltiple» que era el funcionamiento del coro en el lirismo griego $^{51}$.

«Las líneas que forman el territorio de la lírica [...] conforman un tejido que se desliza siempre hacia el fragmento ${ }^{52} . »$ A través de los poros abiertos, de las hendiduras blancas, el texto se ha vaciado de su referente "comme une conque débarrassée de l'être qui y habitait, [qui] retient dans la vacuité de ses spirales transformées en caisse de

${ }^{48}$ Henry GIL, op. cit., p. 23.

49 Jean-Claude PINSON, op. cit., p. 113.

${ }^{50}$ Henry GIL, op.cit, p. 50

${ }^{51}$ Jaime SILES, «La experiencia de la poesía o el lirismo en su historicidad», A qué llamamos arte: el criterio estético, Salamanca, 2001, p. 228.

52 Ibidem, p. 230. 
résonance un son qui est écho.» ${ }^{53}$ Este eco es la nota originaria de la música del poemario, nota que se encontrará siempre en primer plano puesto que resulta de la empresa de dessignificación que rige la escritura. Vaciadas las palabras de su significado, queda solamente el material fónico que las compone y que corre parejas con el material gráfico que lo transparenta. Patentizan el estrecho vínculo entre la música y el agua - la pintura de estas acuarelas - los cuerpos textuados convertidos en plasmación gráfica de esta poética del silencio en la que la disposición tipográfica desempeña un papel primordial - y por ende el blanco, ese estallido luminoso, también. Ya lo apuntaba Henry Gil al mencionar « l'aspect souvent épigraphique et pictographique» ${ }^{54}$ de algunos poemas. Encontramos en V ariaciones en blanco esta forma cerrada en el poema de la página 16 :

Como calla la noche.

Poderosa.

Quietísima.

Fulgen sólo estos ojos

que dirán lo que han visto.

El poema se abre con un símil in absentia puesto que viene introducido por el adverbio de manera pero omite el término comparado, primera manifestación de la oquedad de la vasija textual. Añádase el valor semántico del verbo que remite al silencio y a la oscuridad - ausencia de luz - que caracteriza «la noche». Bien podría identificarse una isotopía del hieratismo en este poema de versos cortos que van del trisílabo al heptasílabo. En efecto, el silencio, el velo discursivo y visual de la nocturnidad, asociados a la calificación que de ella dan los adjetivos destacados por su aislamiento versal. Se la tilda primero de «poderosa», perpetuando en la aliteración vocálica en /o/ y en /a/ que ya dominaba el primer verso su oscura faz. Seguidamente, un superlativo viene a rematar la definición de «la noche» hierática, que bien podría llevar una mayúscula para indicar su carácter totalizador y genérico, siendo en última instancia una alusión a Mallarmé. Su noche es metáfora del dar a luz de la impotencia, como lo atesta la construcción restrictiva del cuarto verso: «fulgen sólo estos ojos...». Otra isotopía es la de la creación-visión, si aceptamos que van de la mano la una con la otra, puesto que tenemos dos términos en posición final de verso que remiten a la vista («ojos»y «visto») asociados con el trabajo del poeta que es el decir («dirán»). $\mathrm{Y}$ es que imperceptiblemente detrás del adjetivo demostrativo «estos» se esconde un «yo» por la localidad a la que remite, designando lo que está cerca de la persona, la voz diríamos en este caso, que habla. La correlación de la voz,

${ }^{53}$ Henry GIL, op. cit., p. 40.

${ }^{54}$ Ibidem, p. 56. 
del decir y de la visión confirman que el sujeto poético se siente él mismo en el acto de creación-visión, en que pasamos de la nada sonora ${ }^{55}$ a la nada visual.

Ada Salas acaba liquidando el lenguaje en el blanco de sus variaciones. En efecto, la poetisa extremeña sistematiza el uso del verso escalonado, del verso simple descentrado o del verso simple centrado, rompiendo con cualquier disposición normativa o tradicional en estrofas habituales. Con esto pretende dar un salto de la nada sonora a la nada visual, aliarlas ambas:

El blanco era un color de connotaciones temibles. Tal vez por su contenido semántico de vacio. Para poder escuchar, percibir el sonido, es necesario el silencio, el espacio de la nada, el más rico, donde únicamente pueden encarnarse todas las reverberaciones..$^{56}$

Qué más recurrente como eco ${ }^{57}$ que el de «lo que abajo suena» o el de «un yo que nadie más repite,/como si el tiempo en él tan sólo fuese/la materia de un soplo sin final». Así en «Identidades» desconocemos el origen de la sucesión de sonidos puesto que la «simpleza» del «agua aquí oculta» y no deja trasparecer. Salas hace estallar las formas cerradas que eran todavía en su mayoría las de Siles. Moldea sus poemas de tal modo que pasamos de la nada sonora de Siles en la que resonaban ecos audibles a una nada visual en la que los blancos son luces intermitentes en esta poesía visual:

Se trata de ser lúcido en la ceguera. Internarse en la selva hasta perderse, esperar a que caiga la noche cerrada y, perdida toda noción de realidad, toda referencia espacial o temporal, abrir los ojos en la negrura, como el búho, y esperar. Y ver..$^{58}$

Vaciarse uno, el lenguaje y el espacio poemáticos: mar que se va y lleva consigo el lastre para mejor devolverlo todo en la explosión sonora y visual de la ola. La lucha entre la textualidad y el silencio acaba con la derrota de la primera y su penetración, su violación por el silencio. De ahí la hibridez, la monstruosidad formal congénita a los poemas de Salas. Afirma ella que «la labor poética es algo mucho más vertiginoso: se escribe en el vacío, en el caos. ${ }^{59}$ Le corresponde en parte al lector poner cierto orden a este estado amorfo e indefinido, labor excepcional que se le confía en cualidad de co-autor. De ahí la advertencia dirigida a ambos: «escribir predispone a lo extraordinario: oír lo que no se ve, ver lo que no se oye. Pero cuidado con perderse. ${ }^{60}$ En este quiasmo radica la tarea del lector, crítico y co-autor del poema, suscribiendo enteramente al postulado silesiano que sostiene que "no es lo que el lenguaje da, sino lo que el silencio niega.»" ${ }^{61} \mathrm{Y}$ para no perdernos en sus notas sobre la escritura poética, Ada Salas nos da la clave de empleo, de

\footnotetext{
55 Postulado silesiano.

56 Ada SALAS, Alguien..., p. 25.

57 Ada SALAS, Alguien..., p. 83.

58 Ibidem, p. 43.

${ }^{59}$ Ada SALAS, Alguien..., p. 48.

${ }^{60}$ Ibidem, p. 108.

${ }^{61}$ Citado ya anteriormente.
} 
lectura, del blanco ${ }^{62}$. Así, la poetisa nos autoriza a decir de sus textos que son acuarelas poéticas, insistiendo así en el carácter visual de los mismos. Parece pues que la poesía de ambos radica en ese «trou béant entre les formes fixées» ${ }^{63}$, en ese género inconstituido e inconstituible debido a «l'infidélité des moyens d'expressions.» ${ }^{64}$ Partiendo de esta observación, Christian Prigent afirma que «la poésie veut s'approprier le réel, mais le réel comme impossible (comme manque) ${ }^{65} . »$ Esta carencia, este imposible hacen que su meta sea la de crear «des objets énigmatiques, in-signifiants, énergiques et stupéfiants, qui dérobent "le connu dans l'inconnu". ${ }^{66}$ Este arranque repercute en la estética de las obras y les inyecta o las somete a un nuevo proceso creador, el de la deconstrucción.

A menudo poesía es sinónimo de ruptura con los fundamentos preestablecidos - en el caso del lenguaje se trata de los principios aristotélicos que le dictan su funcionalidad -, con las definiciones fijadas o a priori « pour accéder à un nouveau code langagier susceptible de dire ce qui ne pourrait être dit autrement» ${ }^{67}$, porque «el poeta deshace.»» ${ }^{68}$ Se presenta pues el proceso como una negación incluso metafísica, ya un Siles «affirme [...] que cet ensemble de signes qui compose le ou les poème(s) n'est pas produit par le langage mais par le silence lui-même.» ${ }^{69}$ Ada Salas adopta también esta técnica puesta de relieve. Analicemos el segundo poema liminar de Variaciones en blanco:

\author{
Aire herido de paz. \\ Deshojado dolor. \\ Lento río
}

de rosas

apagadas.

Impera de entrada el sufrimiento al que remite el diptongo inicial así como la repetición de la vibrante simple /r/ y la ósmosis entre la atmósfera y el sufrimiento que pone de manifiesto la sinalefa. Cabe señalar la paradoja del primer verso puesto que la tranquilidad es fuente de tormento, en esta personificación de un elemento invisible - el «aire» - que patentiza la lucha por transcribir aquello que no se puede ver: se someten pues no sólo la mirada sino también la imaginación y la mente a la realidad creada por la palabra. Igualmente relevante es la monotonía creada por el paralelismo rítmico de los dos primeros versos, ambos oxítonos. Así la ausencia de conflicto incurre en uniformidad, en falta de variación que termina por desgarrar hasta el texto mismo. El blanco aquí sugiere tanto la

\footnotetext{
62 Ada SALas, Alguien..., p. 74.

${ }^{63}$ Christian PRIGENT, op. cit., p. 210.

${ }^{64}$ Christian PRIGENT cite Francis PONGE in op. cit., p. 213

${ }^{65}$ Christian PRIGENT, op. cit., p. 213.

${ }^{66}$ Christian PRIGENT cita a Georges BATAILlE in op. cit., p. 214.

${ }^{67}$ Henry GIL, op. cit., p. 52.

68 Ada SALAS, Alguien..., p. 62.

${ }^{69}$ Henry GIL, op. cit., p. 52.
} 
paz, la calma, como la pérdida de color por causa de ese «deshojado dolor.» El sangramiento textual que ponía de manifiesto la mordedura logofágica se disemina en la carga semántica de los dos primeros versos, que terminan revelando a una Dafne cuyo único atributo es ya el desgarramiento, puesto que el laurel ha perdido hasta sus hojas. El poema no es una narración versificada del consabido mito, pero la ausencia de verbos conjugados nos sume en una temporalidad propia de la leyenda. Asistimos a un cuadro de gran intensidad dramática gracias a la creación de una amplia red de correspondencias implícitas de gran poder evocador: el dolor se nos muestra tal cual, desnudo, «deshojado»; pero la elección de este término no es baladí ya que las hojas del amor de Apolo se han caído y han ido a parar en el árbol en el que se ha convertido la ninfa, recordando los versos del soneto de Garcilaso: «Aquél que fue la causa de tal daño/a fuerza de llorar, crecer hacía/este árbol, que con lágrimas regaba.» No olvidemos que Apolo, dios de la lira, inspiraba en la Antigüedad a los poetas y bien podría ser aquí trasunto de la voz poemática, tanto más cuanto que su llanto ya en los versos del poeta renacentista se volvía «río» que «regaba». Se procede a un vaciamiento progresivo para alcanzar la sustancia primigenia que desarrolla el escalonamiento de los versos siguientes.

Asegura la perfecta trabazón con el poema liminar la reaparición del adejtivo «lento», confirmando así un tiempo en suspensión, un universo manso y acuático que ora fluye paulatinamente ora se detiene, devorado por el vacío que permite dibujar el serpenteo del cauce. De modo que la imagen aquí la crea no principalmente lo que el discurso dice sino más bien lo que el silencio calla. De ahí el juego métrico que consiste en dislocar un heptasílabo o un endecasílabo. Toda tentativa de grafiar y de avanzar en el proceso de construcción textual acaba perdiéndose, o encontrándose en la deconstrucción que nos conduce al origen, a una nueva línea. Y como las «rosas» que fluyen se marchitan y deslucen, así las letras y palabras «apagadas» no son más que reverberación, remanente sonoro y visual sostenido por la asonancia en /a/ que amortigua no sólo el color y la luz sino que indica que todo tiende a la extinción. In fine de lo que se ha glosado en el poema ha sido la muerte, a lo que nada resiste. Tres escalones en este proceso que conduce de la vida a la muerte: la nada que es la inmovilidad inicial, el movimiento y sufrimiento que es el combate del texto con la logofagia y la nada que es también el blanco final.

Esta deconstrucción lleva a Ada Salas a cuestionarse: «construir. Construir qué. Socavar, a golpe de palabras.» ${ }^{70} \mathrm{La}$ deconstrucción ontológica y semántica acaba mermando la forma misma del poema. Se pasa de la «escritura del vacío» al «vacío de la escritura» en términos de Juan José Lanz, vacío plasmado por los blancos tipográficos en la escritura salasiana que borra los márgenes de la aparente aporía silesiana de «Final», resultando en una forma informe, en un espejo en pedazos. La poesía se ha transformado en otra cosa. «Et cette "autre chose" est l'énigme dont la résolution, toujours différée, est l'objectif même du travail d'écriture dit "poétique".»" En efecto, la errancia temática de Variaciones en blanco propone una lectura sinuosa: no hay ni secciones ni títulos. Es que según, la poetisa extremeña, «el poeta no [...] camina para llegar, sino para perderse: sólo de la errancia, del abandono, surge el poema.» ${ }^{72}$ De ahí que también sus poemas tengan un carácter casi inclasificable por su profusión formal. En todo caso, para la poetisa el reflejo se vuelve

\footnotetext{
${ }^{70}$ Ada SaLas, Alguien..., p. 112.

${ }^{71}$ Christian PRIGENT, op. cit., p. 209.

72 Ada SALAS, Alguien..., p. 37.
} 
auto-reflejo: numerosos poemas son metapoéticos. La escritura de Ada Salas resulta en una escritura de lo instantáneo, porque sólo en la intensidad del instante se roza lo eterno. En su poemario, cada texto parece incluso gozar del estatuto de electrón libre y beneficiar de su autonomía. Muchos textos no tienen solución, sea que se den por instantáneas que se bastan por sí solas, sea que constituyan investigaciones inciertas. El conjunto de estos aspectos contribuye al efecto de fragmentación. Sin embargo, los pedazos siguen remitiendo a un mismo espejo. Por eso hablamos de deconstrucción constructora. La obrafragmento escapa a la dilución, se solventa ésta integrándose en un poemario. A nivel microestructural, cada texto mantiene con los demás un vínculo oblicuo y se debe «descubrir la secreta coherencia del libro» ${ }^{73}$.

Efectivamente, es posible identificar ecos temáticos entre unos textos y otros. Por ejemplo, podríamos citar el tema del dolor y del placer que en Variaciones en blanco encontramos en las páginas 15, 16 y 41. También es recurrente el tema del poeta visionario que hemos destacado en las páginas 21, 24 y 42. Como última ilustración se podría mencionar el tema del fuego que permite asociar al poema de la página 16 con el de la página 29.

Por otra parte, el aparente desorden del poemario de Ada Salas presenta un orden sinuoso que remite a las mismas obsesiones, estableciendo verdaderos ecos semánticos entre varios textos. La sombra es quizá la obsesión más recurrente y citamos por ende las numerosas páginas en la que aparece: 11, 18, 21, 22, 25, 26, 27, 36, 38. Le sigue la soledad en términos cuantitativos de presencia textual, véanse las páginas 14, 19, 21, 28, 39 por ejemplo. En todo caso, hay poemas que hasta en su estructura misma se llaman unos a otros; yuxtapuestos en las páginas del poemario, se encajan visualmente entre sí creando una tensión supra-textual que hace entrar en una acción recíproca dos páginas entre sí. Remitimos a la interacción de las páginas 16-17, 20-21, y 28-29.

Otra manera de escapar a la dilución es integrándose, a nivel macroestructural, en una obra. En lo tocante al poemario de Ada Salas, tras la experiencia de Variaciones en blanco, el punto final del último poema hace que se pregunte «cómo abrir[á] de nuevo la puerta hacia Lugar de la derrota.» ${ }^{74}$ Pero no sólo se integran los poemarios en una obra propia a cada autor sino que se integran también en una intertextualidad externa, qué mayor prueba que las correspondencias que se han esbozado aquí entre Jaime Siles y Ada Salas. Aludimos, por ejemplo, a un poema ${ }^{75}$ de Variaciones en blanco que bien podría formar un tríptico con «Introito» y con «Final» de Música de agua. Al igual que el poema liminar de Música de agua, en dicho texto de Ada Salas tenemos un poema del principio de los tiempos, o de un tiempo originario, primigenio, recreando un estado de gracia en que se conjugan los elementos de la poesía silesiana y salasiana. Ambos poetas recurren a «construcciones simbólicas acuáticas características del Barroco.» ${ }^{76}$ La salida y dirección de esta vía parecen ser el silencio, el blanco de la página, la ausencia de ecos. Podemos decir con Henry Gil que «la langue en se recourbant constamment sur elle-même produit un texte autotélique et

\footnotetext{
${ }^{73}$ Ibidem, p. 85.

74 Ada SALAS, Alguien..., p. 91.

75 Ada SALAS, Variaciones..., p. 51.

${ }^{76}$ Juan José LANZ, art. cit., p. 349.
} 
centripète, comme clos sur lui-même»» ${ }^{77}$; de ahí la necesidad de descuartizarlos, de ahí que sus propiedades y principios emanen de y obedezcan a una metafísica de la desintegración de la obra.

\section{III - UNA METAFÍSICA DE LA CONSUMICIÓN}

La obra-fragmentos se encuentra en busca de una difícil cohesión, mostrando cuán sometida está en realidad - por una implosión centrípeta - a fuerzas centrífugas que permiten cuestionar su estatuto poético y más aún su estatuto de obra. Christian Prigent habla de este:

formalisme dont la modestie rusée tend à rentrer le langage poétique en lui-même et à faire naitre du cœur même de la langue (sans référence à un « dehors») des « histoires » qui sont à chaque fois comme de petits romans «du signifiant» et qui refont du sens sur l'absence assumée de sens. ${ }^{78}$

Con el crítico, observamos las " archipélisations "blanches"» ${ }^{79}$ que son estos poemas, archipiélagos circundados por aguas que brotan de la fuente heideggeriana, como ya otros lo han apuntado. El poema se vuelve puro instante, es un evento en sí, fotografía del momento de la escritura y de su proceso, apocalipsis. Un Denis Roche afirma pues que no tiene nada que decir más que su «violente action d'écrire». La obra, su sentido comprendido como dirección-, no deja de apuntar hacia los caminos sin salida contra los que choca, las fronteras que la enmarcan y que transgrede gracias a una señalización radical - el blanco - «pour se déplacer immédiatement ailleurs» ${ }^{80}$ ». Espiral viciosa y virtuosa hecha de pura tensión, de una exigencia que se funda en un rechazo - el de la comodidad - y en el mantenimiento de "la tension tragique dans des formes dont on ne peut rien dire» ${ }^{81}$ porque su principio es el eterno cuestionamiento de sí mismas. Violencia que ejercen contra sí mismas ya que "accéder à la dignité de l'œuvre serait, d'une certaine manière,

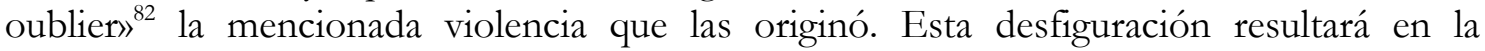
simbolización de las fuerzas que entran en juego en el acto de escritura en fragmentos caleidoscópicos víctimas del derrumbamiento y de la experiencia límite de la tensión, enmarcada en la metafísica de la consumición que caracteriza esta obra.

Bien podríamos aplicar a los textos de Ada Salas la expresión con la que Walter Benjamin analizaba la escritura de Baudelaire. Son nuestros textos fiel ilustración de la «poética del choque», ya que no hay en ellos lugar para cuadros de beatitud: «uno debe

\footnotetext{
${ }^{77}$ Henry GIL, op. cit., p. 59.

${ }^{78}$ Christian PRIGENT, op. cit., p. 215.

${ }^{79}$ Ibidem, p.156.

${ }^{80}$ Ibidem, p. 161.

81 Ibidem, p. 119.

82 Ibidem, p. 121.
} 
enfrentarse al poema vacío, blanco de intención y, a ser posible, de deseo.» ${ }^{83}$ Lucha, combate con el texto que pone de manifiesto la obligación, el deber del lector según Ada Salas. Posición inconfortable pues en la que también se ve relegado el lector, en quien se produce un malestar que no deja de ser placentero. Es que «l'œuvre n'est pas l'unité amortie d'un repos. Elle est l'intimité et la violence de mouvements contraires qui ne se concilient jamais et qui ne s'apaisent pas, tant du moins que l'œuvre est œuvre..» ${ }^{84}$

Algunos poemas de Ada Salas aúnan explícitamente la voz poemática y la oscuridad o la muerte, estableciendo un claro vínculo entre la escritura, el tiempo y la progresiva aniquilación. El tiempo que fascina al sujeto poético se entiende en este caso como lo define Maurice Blanchot: «en lui ce qui apparait, c'est le fait que rien n'apparaît, l'être qui est au fond de l'absence d'être, [...] la présence de l'absence.» ${ }^{85}$ Así, en el poema «Honda en la noche... ${ }^{86}$, la sinalefa que acerca aún más el adjetivo que califica a la voz poemática y la oscuridad en la que se encuentra pone de manifiesto la ósmosis entre la una y la otra. Todo apunta hacia la destrucción: el aislamiento del acto de escritura, lo que de él resulta y que es total decadencia tanto más violenta cuanto que su inanición proviene de un tiempo desgranado («las horas») y «enfermo». Tiempo que se dilata en el plural de sus momentos y cuyo dolor se eterniza por un lento, un "pausado morir de la nostalgia.» La voz poemática se convierte en apátrida cuya pena ni siquiera existe y no puede ni aferrarse a ella: hasta su tristeza originada por el recuerdo de una dicha perdida la abandona. Ningún refugio pues para el sujeto lírico, privado no sólo de sus recuerdos sino del sentimiento mismo de desazón que el desvanecimiento de éstos provoca. De manera que asistimos a una violenta disgregación del ser que lo conduce hasta su desaparición, «comme s'il n’y avait des êtres que par la perte de l'être, quand l'être manques ${ }^{87}$ :

Ni la invisible seda de tu aliento.

$$
\begin{aligned}
& \text { Yo. } \\
& \text { Perdida. } \\
& \text { Perdida } \\
& \text { como niño }
\end{aligned}
$$

que abandona sus ojos en la orilla del llanto..$^{88}$

Los versos citados empiezan de entrada por una doble negación si observamos la conjunción y el adjetivo que determina a «la invisible seda». La suavidad contenida en este primer verso («seda», «aliento») es más motivo de angustia que de tranquilidad por su ausencia que patentiza la carencia de los elementos. No hay dulzura del aire, no hay respiración, no hay vida o impulso vital, no hay espíritu ni alma. El umbral del poema es

83 Ada SALAS, Alguien..., p. 54.

${ }^{84}$ Maurice BLANCHOT, op. cit., p. 300.

${ }^{85}$ Maurice BlanCHOT, op. cit., p. 26.

${ }^{86}$ Ada SALAS, V ariaciones..., p. 34.

${ }^{87}$ Maurice BLANCHOT, op. cit., p. 26.

88 Ada Salas, Variaciones..., p. 35. 
ausencia total, es el borde de un abismo en el que hasta el lenguaje se pierde: adviértase la fragmentación del endecasílabo del medio en versos cortísimos, constituidos como máximo de dos palabras, versos nominales que remiten a una esencia de la desorientación más absoluta que se vuelve retroceso, regresión al estado originario de la infancia, es decir al estado de aquél que no habla (recordemos la etimología latina infans). Y si el único garante del ser de la voz poemática era el lenguaje, ya sin él nada queda. Se había insistido en el papel del poeta visionario que se le atribuye a la voz poemática en estos textos. Y aquí hasta «abandona sus ojos», pierde toda posibilidad de ver y por ende de crear. La violencia del símil no deja de ser desgarradora y quizá el lector también se encuentre «en la orilla del llanto.» En el fondo, se da a ver la vida de contención y de lucha en que estamos sumidos, imperando el cariz de la melancolía y de la desesperanza porque hasta el lenguaje nos traiciona ya que es «líquida lengua que lame toda luz» y que «termina el mar en [él], termina el mundo.» ${ }^{89}$ La modernidad de estos textos, tejida de transitoriedad y de eternidad, radica en el presentimiento que tienen de que el mundo se acaba. Y es que «l'art moderne a une tendance essentiellement démoniaque. ${ }^{90} \mathrm{La}$ presencia del diablo, fuera de toda comprensión religiosa, sugiere a través del adjetivo la soledad y la violencia, las del blanco de la página contra el que lucha la voz poemática, blanco que es al mismo tiempo su única posibilidad de realización. El sujeto se encuentra solo en la noche, momento en que ha perdido su combate.

El poema «Delgada soledad...»" ${ }^{91}$ se abre con una invocación a la soledad que la personifica en una dama, o en una música o cantante si tenemos en cuenta lo que dicen los versos siguientes. El protagonismo de la soledad es notable: la apóstrofe abre el texto con la invocación a una materia tanto más evanescente cuanto que es «delgada» y que se esfuma incluso en las sonoridades dentales y líquidas $(/ \mathrm{d} / \mathrm{y} / \mathrm{l} /)$ de este primer verso. La sílfide es tan invisible como el blanco que disloca este eneasílabo, su delicadeza y fragilidad están contenidas en el adjetivo y en los signos gráficos que componen las palabras. La voz poemática por su parte se encuentra en espera. Nótese entonces su estatismo que se opone al movimiento («ven») de la protagonista. Lo único que se requiere es la presencia de la Ausencia, y para ello se ponen en escena las condiciones necesarias al acto de escritura: el inicio de ésta es el «desasimiento paulatino de la vida, del yo nuestro en el mundo» ${ }^{92}$ que nos conduce al «vacío, silencio, soledad». El poema ilustra este recorrido y proceso, pidiendo a la soledad que sea sibila que guíe al nuevo Eneas en que se ha transformado la voz poemática y que está por sumirse en las oscuras profundidades del blanco, de la «cueva primigenia» ${ }^{93}$ para encender su antorcha. Esta no se constituye de fuego sino de «una serie de sonidos vibrantes pulsados en un instrumento invisible, incorpóreo.» ${ }^{94}$

La sibila luego se ve transformada en Orfeo y van surgiendo a borbollones las notaspalabras de este canto a la musa. Basta con observar el verbo «pulsa» y el encabalgamiento abrupto provocado por la dislocación versal. La metáfora que sigue pinta el «instrumento

\footnotetext{
${ }^{89}$ Jaime SILES, «Líquida lengua», Música..., p. 72.

90 Charles BAUDELAIRE, L'Art romantique, version en ligne sur le site de la BNF: http://gallica.bnf.fr/ark:/12148/bpt6k101426n

91 Ada SALAS, Variaciones..., p. 14.

${ }^{22}$ Ada SALAS, Alguien ..., p. 14.

${ }_{93}$ Ibidem, p. 15.

${ }^{94} \mathrm{Ibidem}$, p. 31.
} 
invisible» del que habla Ada Salas, asociando en última instancia la visión, el tacto y el oído. De esta manera se produce la música, revelando la confusión del origen sinestésico del sonido: «no podemos precisar su procedencia.» ${ }^{95}$ La soledad se convierte en guardiana de la creación poética, responsable del advenimiento de una sola voz; la realidad se vuelve extraña ya que apunta hacia la posibilidad de un desdoblamiento, de un desasimiento de la voz poemática. Esto nos obliga a estar siempre en una «espera vigilante, alerta.» ${ }^{96}$

Violencia constitutiva también del placer masoquista que se ha comentado anteriormente y que trasparece en algunos poemas. Violencia incluso del léxico que remite a la guerra o al combate: «batalla», «espada», «guerra» son términos que indican la lucha entre la voz poemática y la poesía, entre el domador y la bestia salvaje cuyo territorio es indómito, cruel y resistente ${ }^{97}$.

El enfrentamiento se desarrolla en una «selva de silencios» que la poesía yergue contra el sujeto lírico. La oposición es tanto más evidente cuanto que viene realzada por un blanco tipográfico que insiste en la preposición «contra» que denota el enfrentamiento entre ambos. La geografía del terreno poético es hostil a la marcha del sujeto lírico, quedando destruido el tópico de la harmonia mundi. En vano la voz poemática le recuerda a la poesía que «h[a] bebido en la espalda/profunda/de [s]u boca», dicha unión sensual no tiene actualidad ninguna puesto que ahora el paisaje que le ofrece se compone de un «airado río»y de una «feroz cordillera». Lógico es el «altísimo/temon» suscitado en el sujeto lírico, presa del «hambriento animal/de la palabra.» Las cuatro exclamaciones indirectas que jalonan los lances del poema apoyan la intensidad de la violencia ejercida contra el sujeto poético que el poema acaba destruyendo, imponiéndosele:

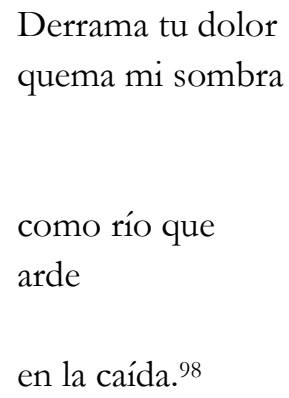

La cascada de palabras ya no reduce a cenizas la voz poemática sino su «sombra», lo demás ya ni siquiera existe. En el agua ardiente - porque quema y porque es roja de la sangre que en ella corre - muere la voz poemática, como muere el segundo heptasílabo de la composición dislocado en un pentasílabo y un bisílabo.

Sorprende asimismo la violencia de algunas imágenes conjuradas: «tormento es este mar», «isla fiera» que es la poesía, parcela de tierra que emerge de la nada, frágil creación,

\footnotetext{
95 Ada Salas, Alguien..., p. 31.

96 Ibidem, p. 14.

97 Ada SALAS, Variaciones..., p. 24.

98 Ada Salas, Variaciones..., p. 25.
} 
entrevista, apenas percibida. La tendencia demoniaca del arte moderno opera también en el poema dedicado a Luzbel:

Ángel

era

y en su vuelo

la luz

el aire de sus alas ${ }^{99}$.

La caída progresiva del ángel más bello es dibujada por la disposición tipográfica y el escalonamiento de los versos. La introducción de este personaje sugiere la discordancia. Esta alcanza hasta el sujeto mismo que trata de desaparecer, ora desdoblándose ora pluralizándose. En Variaciones en blanco, el sujeto es a su vez personaje (p. 20), testigo (p. 17), espectador doloroso y doliente (p. 15), entre otros. La pluralización del sujeto lo conduce a su casi desaparición elocutoria, para hablar en términos mallarmeanos, en cuanto su voz expresa a su vez su subjetividad y la de otros. La violencia no es sólo un tema, es constitutiva del modo de relación a sí mismo y al otro.

El sujeto poético se busca más de lo que se deja ver, se revela como inestable, extraño y extranjero a toda elaboración mítica. De ahí las ruinas sobre las que se construyen los poemas, ruinas de versos que muestran que:

l'identité de celui qui écrit est, dans ce mouvement, toujours en question, toujours énigmatique, toujours vouée à faire l'expérience infixable d'elle-même. De l'autre, il ne sait rien, parce qu'il ne sait pas grand-chose non plus du même (du Je, qui est un autre). ${ }^{100}$

De esta imposible fijación y de la fragmentación resultante de la violencia de las interacciones entre los diferentes agentes y fuerzas que participan en la creación poética lo único que podemos obtener es un caleidoscopio fragmentario.

La hibridación, la monstruosidad podríamos decir, de este caleidoscopio pasa por una escritura de la logofagia en la que la textualidad se devora a sí misma. Túa Blesa, crítico español, plantea el reconocimiento y la caída del escritor en el «vacío de la palabra» ${ }^{101}$, del escritor que se sume en «el abismo del silencio.» ${ }^{102}$ Nótese ya la dimensión metapoética de estas observaciones y de los textos a los que se aplican. La relación que se establece pues entre el silencio y la escritura concierne particularmente a aquellos espacios discursivos que se interrogan a sí mismos sobre su condición, su origen, su función, su objetivo, espacios

\footnotetext{
${ }^{99}$ Ada SALAS, Variaciones..., p. 50.

${ }^{100}$ Christian PRIGENT, op. cit., p. 129.

101 Túa BLESA, «Logofagias, los trazos del silencio», Tropelías, 1998, p. 15.

102 Ibidem.
} 
discursivos en fin que plantean y se plantean «su propio enigma.»" ${ }^{103}$ Se trata aquí de una escritura cuyo reflejo, cuya imagen es la del tonel de las danaides, tragándose a sí misma: es lo que Túa Blesa llama logofagia.

A pesar de esta reflexión sobre el texto y sus límites, «el escritor de la logofagia [...] no renuncia a continuar su tarea», ${ }^{104}$ y termina - después de haberse sumido en un más allá del lenguaje - reproduciendo el silencio en el cuerpo mismo del texto. Así, el silencio deja de ser únicamente tema y se convierte en «una manera en la que la textualidad se devora, se consume a sí misma, en un gesto de autoinmolación. ${ }^{105}$ No obstante, tampoco se trata de una aniquilación del texto, sino más bien de un oxímoron genérico puesto que «el discurso y el silencio [...] ya no se oponen, no se niegan, sino que se alían.» ${ }^{106} \mathrm{Y}$ de esta alianza incestuosa nacen los textos logofágicos que bien se diseminan a sí mismos en el blanco, bien incorporan en su tipografía al silencio. Es dar un paso hacia la transcripción, hacia la plasmación gráfica del silencio.

El blanco convoca a un lector que debe tomar parte en el proceso creador de la visión. Ada Salas no cree " en el poema "perfecto", en el sentido etimológico de "acabado". El texto debe escaparse a la percepción, a la exégesis, por un punto de fuga de misterio.» ${ }^{107}$

Y si «la diferencia de visiones poéticas del mundo depende del adverbio de lugar en que se sitúe ese hueco» creado por la escritura es también porque ese adverbio continúa remitiendo a un sujeto lírico que puede ahora ser plural y encontrarse en una multiplicidad de marcos espacio-temporales.

El carácter fragmentario del conjunto diverso y variante de poemas que constituyen Variaciones en blanco hace de cada uno de ellos una hostia pagana, recalcando el carácter sagrado de la consumición textual, de la inmolación de la palabra que es:

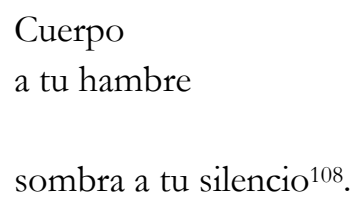

Palabra que en fin es sólo el reflejo pálido de la luz cegadora de la Nada. Palabra que se impone como el único recurso capaz de velar el horror del vacío abismal ${ }^{109}$. La palabra que la vasija temporal no deja de hacer resonar en sus recovecos es el nombre de un tú, de un tú que por tanto es una suerte de nuevo dios. De ahí que quizá se trate del poema mismo, de los trozos textuales que generan la logofagia o la traducen, mostrando la autoinmolación del texto:

\title{
Lágrima
}

\author{
103 Ibidem. \\ 104 Ibidem. \\ 105 Ibidem. \\ 106 Ibidem. \\ 107 Ada SALAS, Alguien..., p. 32. \\ 108 Ada SALAS, Variaciones..., p. 27. \\ 109 Ibidem, p. 47.
}


blanca

ausencia pura

herida

océano de viento desangrado. ${ }^{110}$

La materialidad del agua se esfuma en la transparencia y en el imposible asimiento del «viento», a su vez vaciado de toda sustancia vital y por ende irrealizado, desposeído de su ser que de entrada era tenue. $Y$ es que esta poesía paria en su escritura fragmentaria es esa visión extraordinaria de lo que no se ve y esa escucha sobrenatural de lo que no se oye. Poesía paria en su carácter fugitivo que patentiza la brevedad de las piezas, todas sugerencias y ninguna o raras aserciones. Casi la totalidad manifiesta un fluir imparable de elementos los unos más evanescentes que los otros. Gesto vano el del aire en el poema «Oscuro....» ${ }^{111}$, puesto que por esencia no puede asirse a nada y aquí mucho menos en cuanto trata de agarrarse a la proyección inmaterial de un cuerpo, a la «sombra». Se pinta un poema breve que es «el trozo de mosaico que lleva en sí la clave del mosaico total, que [...] lo sugiere, que conduce a él porque en él están las huellas fundamentales de lo que falta.» ${ }^{112}$ Con esta frase equipara Ada Salas al escritor con un arqueólogo. Pero como trozos de mosaico, la poesía sigue siendo paria en su carácter autónomo. En efecto, se pueden establecer paralelos u oposiciones entre los textos, pero cada pieza tiene su autonomía. Si se puede ver una oposición de claroscuros entre las páginas 53 («niebla»), 54 («nieve»), 55 («deslumbrado», «Oscuro») y 59 («negro») de Variaciones en blanco, no deja cada texto de ser independiente y de dar a su vez una definición de la poesía que, aunque sea la misma, puede desprenderse de la lectura individual de cada poema. Poesía forajida en su carácter inacabado que realza una paradoja: por más autónomo que sea el poema, abre hacia el infinito de sugerencias e interpretaciones. Por ellos, «l'œuvre arrive, est la fermeté du commencement, mais lui-même appartient à un temps où règne l'indécision du recommencement.» ${ }^{113}$ Puede aplicárseles la definición que da Valéry del poema que se hace «expressément pour renaître de ses cendres», es decir que la lectura no lo agota, que se construye entre creación, intertextualidad y emoción del receptor. Prueba de ello es la dedicatoria personal de Ada Salas a su padre «y a su fértil memoria», primer umbral de entrada en su poemario que despide emoción por parte de la escritora y suscita la simpatía de la sensibilidad del lector. La poetisa escala un grado más de connivencia con su público al poner seis epígrafes que por su disposición tipográfica en la página ilustran dos de los términos del título. La alusión a las Variaciones Goldberg subraya claramente el carácter rítmico de estos poemas que como ellas se componen de un tema único, en este caso la ausencia, ligándolos este fondo discordante común que no una misma melodía. Los otros cinco epígrafes introducen variantes seculares e internacionales de escritores cuyo soplo poético puede sentirse en la respiración de los poemas de la poetisa extremeña, apuntando

110 Ada SALAS, Variaciones..., p. 49.

111 Ada SALAS, Variaciones..., p. 48.

112 Ada SALAS, Alguien..., p. 106.

113 Maurice BLANCHOT, op. cit., p. 17. 
todos a la ausencia bajo su modalidad de la soledad del escritor, del acto de escritura; soledad a la que sólo puede remediar la actualidad de la lectura momento en que el primer lector de su obra que fue el autor se funde con el lector segundo que es todo receptor de la obra, desapareciendo no obstante tras la sensibilidad y el bagaje cultural de este último.

Se niegan las palabras, se niega la voz y sin embargo persisten los ecos entrecortados en Variaciones en blanco. En efecto, con el poemario de Ada Salas la extenuación de lo poemático, entendido como la forma textual, da como resultado una escritura de la desligazón, de los harapos: el escalonamiento y la diversidad de disposiciones tipográficas denuncian la difícil unidad aparente, que reposa únicamente en la verdad del vacío, del blanco, del silencio originario. Es que «uno debe enfrentarse al poema, vacío, blanco de intención $y$, a ser posible, de deseo.» ${ }^{114}$ Detrás de ese «uno» se encuentra tanto el lector como el autor del texto, ambos co-escritores de sentido, de un sentido que es precisamente indicación de lectura, camino que es posible recorrer pero que no excluye arterias divergentes, espiral que no círculo cerrado.

Contribuye plenamente a esa irresolución el presentimiento de que el arte no remite sólo a su creador, sino también a su recepción. La incertidumbre de ésta junto a la angustia de la primera conllevan en sí lo inacabado de la empresa. Lo que descomponen estos caleidoscopios es una experiencia estética y existencial que se vuelve imposible síntesis de un mundo y de un sujeto lírico que se deshacen. Tejidos pues de transitoriedad y de eternidad, los textos se someten a una experiencia límite de la tensión.

Se rinden el escritor y su lector ante la evidencia de la ilusión provisional del arte. El telón de fondo de esta poética es existencial y sólo muestra un mundo vaciado, una ausencia total de autoridad metafísica. En efecto, si en Variaciones en blanco la voz poemática hace plegarias, éstas van dirigidas a entidades que son pura ausencia, tales como la «oscura soledad ${ }^{115}$ o la «cálida muerte.» ${ }^{116}$ Lo único patente es la ausencia del líquido vital que es el agua, no se ve «ni la sombra del mar.» ${ }^{117}$ La repetición de la expresión el «oscuro reclamo de mi nombre» nos revela un sujeto poético en busca de su esencia ausente y furtiva dentro de la ilusión provisional del arte que tapa fugitivamente el abismo, como es fugitiva la niebla que constituye las alas del «caballo silencio» ${ }^{118}$, nuevo Pegaso, nuevo caballo alado que bien podría ser símbolo de esta poesía hecha de silencio y de evasión semántica, borrosa y difuminada. Es que se pone:

Sobre la tersa soledad

la nieve ${ }^{119}$.

114 Ada SALAS, Alguien ..., p. 54.

115 Ada SALAS, Variaciones..., p. 69.

116 Ibidem, p. 58.

117 Ibidem, p. 64.

118 Ibidem, p. 53.

119 Ibidem, p. 54. 
Otro elemento, la nieve, que permite velar temporalmente, mientras no se derrita, los trazos, las huellas del silencio. Pero el mismo poema muestra que hasta el velo puede confundirse con lo velado puesto que blanco es el silencio gráfico como blanca es la nieve. Ilusión pasajera del arte porque «la escritura crea (¿es?) un estado permanente de carencia. Su lugar es el hueco.» ${ }^{120}$ Es la noche y más allá o después de ella es lo que se encuentra debajo de ella, el «cero/del principio nocturno/y del final.» ${ }^{121}$

El punto de partida y de llegada es la soledad esencial del escritor de la que habla Maurice Blanchot, del escritor que escribe un libro pero trabaja para la realización de la obra, que lo sobrepasa y supera. Siempre hay tensión para aquél cuyo estatuto mismo es la soledad, como lo muestra el hecho de que sea ésta uno de los pilares de la escritura salasiana. Y es que el poema, eterno ausente, abandona también al poeta.

Si la esencia del poema es su ausencia, el escritor mantiene con él forzosamente una relación de traición. Lo que cuenta para la voz poemática es el canto a secas. Y es que la música es al final el único garante contundente y pertinente, condición sine qua non del poema. La música es en definitiva única fuente de vida perfecta porque induce una circularidad que nos hace ir de «su final» a «su principio», base también de las Variaciones Goldberg de Bach y de las Variaciones en blanco de Salas. En efecto, el poema «Delgada soledad.... ${ }^{122}$ erige a la soledad al rango de nuevo Orfeo y la omnipresencia de sensaciones auditivas no deja duda alguna en cuanto a la importancia atribuida a la música. Igualmente crucial es la escansión de los versos ya que en un poema como «Ya no será la paz...» ${ }^{123}$ la dislocación del segundo heptasílabo en un tetrasílabo y un trisílabo es fundamental para la irrupción del caos que el texto trata de significar. Otro poema de Ada Salas subraya la necesidad de abrazar el silencio dislocando un alejandrino:

\section{Abrazar \\ el olvido \\ olvidar el silencio ${ }^{124}$.}

La estructura quiasmática del verso yuxtapone en el centro - incluso tipográficamente - el olvido y así lo suprime, aproximando el abrazo al silencio, haciendo que la voz poemática asuma su ausencia, que confirma el poema siguiente poniendo en evidencia la fugacidad y la prisa del yo poético en la rápida aliteración en /ir/: «Huirme huir vivir», proceso de fuga que vuelve a comenzar eternamente («de nuevo»). El «yo» se precipita hacia la vida y llega primero a una «claridad infinita» que es momento de beatitud, encuentro de Orfeo con Eurídice antes de la pérdida fatal, cuyo rastro quedará grabado en ese «pequeñísimo labio/que recuerda.» Lo que se ha descrito en los versos de este poema ${ }^{125}$

\footnotetext{
120 Ada Salas, Alguien..., p. 50.

121 Jaime SILES, Música..., p. 65.

${ }^{122}$ Cf. Supra, p. 66.

${ }^{123}$ Cf. Supra, p. 38.

124 Ada SALAS, V ariaciones..., p. 67.

125 Ada SALAS, Variaciones..., p. 68.
} 
es la carrera que en tres tiempos constituye el proceso de fragua del poema: supresión del yo, alcance de la luz cegadora de la nada, materializada por una ínfima parte - el poema de la totalidad ausente.

Innegable es pues la dificultad para plasmar en la obra la carencia originaria; en palabras de Christian Prigent, se trata de una dificultad para:

Sacrifier, par l'œuvre accomplie, la sensation d'inaccomplissement (l'angoisse) qui en a provoqué l'écriture et garder vivante, dans l'œuvre, cette sensation qui en sacrifie d'une certaine manière la plénitude (l'accomplissement esthétique). ${ }^{126}$

Quizá la maestría resida en el intento, la fuerza en su debilidad - Aquiles no sería el mismo sin su talón. Quizá lo admirable sea la huella que conserva el texto del silencio del que se arriesgó a salir y del riesgo que corre de volver a caer en él, ya que «en el proceso de escritura hay muerte y resurrección, como en todo viaje hay despedida y regreso.» ${ }^{127}$ Acabamos admirando, con Christian Prigent, la virtuosidad de «cette fragilité possédée qui, brutalement renversée (là est la décision, dans cette violente conversion du négatif), fait signe affirmatif, ascèse et extase : style.» ${ }^{128}$ Estilo que se debe a la articulación entre dos extremos, gracia que se aprecia cuando las obras surgen de la tensión máxima de esa tirantez que las desgarra - como la voz poemática es desgarrada también - entre ser y no ser.

El poemario de Ada Salas, en el desgarre y la extrema tensión que lo constituyen, es la expresión de una experiencia estética y existencial que se vuelve imposible síntesis de un mundo y de un sujeto lírico que se deshacen. Fraguados en una crisis llamada poesía, los textos rezuman un misticismo desprovisto de cualquier panteón: los poemas se vuelven templos sin altares, sin imágenes a las que consagrarse, salvo el indestructible signo del lenguaje. Este último garantiza la creación de palabras y de silencio, polos extremos cuya articulación asegura también la recreación del hombre que está en busca constante de lo originario. Imposible pasar por alto la resonancia del neoplatonismo en su negativo que evidencian el papel prometeico atribuido al poeta y la reactivación de la teoría de la reminiscencia, ambos invertidos total o parcialmente en cuanto se los confronta al devenir heraclíteo. Es que por una parte se quiere pulsar el Ser, la esencia que sin embargo se revela fugaz; por otra parte se consigue sólo pulsar un ser, el del lector que se solicita activamente en la creación de sentido. Implicado en el descifrar de los jeroglíficos sígnicos, el lector es presa de un vértigo ontológico y lingüístico que resulta de una poética del estallido luminoso. Dicha explosión saca a la luz el dilema de una voz poemática que se busca a sí misma más de lo que se encuentra, que ora desaparece ora resucita en fragmentos de identidad, voz tan fragmentaria como los poemas que de ella surgen. En efecto, el recurso a

${ }^{126}$ Christian PRIGENT, op. cit., p. 130.

127 Ada SALAS, Alguien..., p. 140.

128 Christian PRIGENT, op. cit., p. 136. 
la nada visual patentiza la vacuidad de las cajas de resonancia que son los poemas, elaborados a partir de una estética de la deconstrucción que merma lo poético y lo poemático:

[...] dans ce langage tout retourne à l'affirmation, que ce qui nie, en lui affirme. C'est qu'il parle comme absence. Là où il ne parle pas, déjà il parle ; quand il cesse, il persévère. Il n'est pas silencieux, car précisément le silence en lui se parle. ${ }^{129}$

Con todo, logran escapar a la dilución integrándose en un poemario, en una obra y en una intertextualidad externa. Pero, llevada hasta sus últimas consecuencias, la experiencia podría llegar hasta un punto límite de no retorno y producir textos cerrados sobre sí mismos. Con el fin de abrir el abanico de posibilidades creadoras al infinito no queda más solución que descuartizarlos, franquear las fronteras del abismo, sumergirse en él e integrarlo:

Le poème - la littérature - semble lié à une parole qui ne peut s'interrompre, car elle ne parle pas, elle est. Le poème n'est pas cette parole, il est commencement, et elle-même ne commence jamais, mais elle dit toujours à nouveau et toujours recommence. ${ }^{130}$

De modo que se vuelve principio de escritura de estos poemas una metafísica de la consumición. Poseen en efecto una violencia constitutiva tributaria de la discordancia del caleidoscopio fragmentario que forman los textos. Su carácter heteróclito prueba que se someten a una experiencia límite de la tensión. Libro de fragmentos, de harapos o jirones, mas libro sin embargo, el poemario no tiene fin en sí mismo, está y es abierto, sin cola ni cabeza. El desgarre del texto y del sujeto que los opera sirven de pasadores. En ese sentido el texto es bien pasaje hacia la obra que es como el fruto prometido mas nunca alcanzado de una melancolía del arte y del pensamiento.

129 Maurice BLANCHOT, op. cit., p. 55.

130 Ibidem, p. 35. 